\title{
Polychlorinated Biphenyls Contamination of Sludge in India
}

\author{
Khageshwar Singh Patel1 ${ }^{*}$, Shobhana Ramteke1, Bharat Lal Sahu1, Yogita Nayak1, \\ Saroj Sharma ${ }^{2}$, Chin-Chang Hung ${ }^{3}$ \\ ${ }^{1}$ School of Studies in Chemistry/Environmental Science, Pt. Ravishankar Shukla University, Raipur, India \\ ${ }^{2}$ Department of Chemistry, Devi Rathi Mahila Mahavidhaya, Rajnandagaon, India \\ ${ }^{3}$ Institute of Marine Environmental Chemistry and Ecology, National Taiwan Ocean University, Taiwan \\ Email: "patelks55@hotmail.com
}

Received 4 September 2015; accepted 18 October 2015; published 21 October 2015

Copyright (C) 2015 by authors and Scientific Research Publishing Inc.

This work is licensed under the Creative Commons Attribution International License (CC BY).

http://creativecommons.org/licenses/by/4.0/

c) (7) Open Access

\begin{abstract}
Polychlorinated Biphenyls (PCBs) exist in all compartments of the ecosystem due to wide industrial applications and production during burning processes. The PCBs congeners were quantified in the industrial, municipal and agricultural wastes of the most industrialized area of the country, Raipur city, India. The concentration of $\Sigma$ PCBs in the sludge, sewage and agriculture wastes $(n=4)$ was ranged from $497-800 \mu \mathrm{g} / \mathrm{kg}$ with mean value of $634 \pm 146 \mu \mathrm{g} / \mathrm{kg}$. The PCBs congeners detected in the waste materials were ranged from $56-85$ with mean value of $75 \pm 13$. The highest number of congeners was quantified in the sludge materials due to the existence of the heavy PCBs. The PCBs congeners were found to decrease vertically due to the adsorption by the geo-media. The distribution, sources and toxicities of PCBs congeners in the waste materials are discussed.
\end{abstract}

\section{Keywords}

Polychlorinated Biphenyls, Sewage, Sludge, Contamination

\section{Introduction}

The persistent organic pollutants (POPs): DDT, aldrin, dieldrin, endrin, chlordane, heptachlor, hexachlorobenzene, mirex, toxaphene, polychlorinated biphenyls (PCBs), dioxins, furans, etc. are toxic chemicals that adversely affect human health and the environment around the world [1]. They frequently occur in the Asian environment due to their large use in industrial and agricultural sectors as well as production during burning processes [2]. Polychlorinated biphenyls (PCBs) are a class of organic compounds having a basic chemical

"Corresponding author.

How to cite this paper: Patel, K.S., Ramteke, S., Sahu, B.L., Nayak, Y., Sharma, S. and Hung, C.-C. (2015) Polychlorinated Biphenyls Contamination of Sludge in India. American Journal of Analytical Chemistry, 6, 867-877.

http://dx.doi.org/10.4236/ajac.2015.611082 
structure "I", which include two benzene (biphenyl) rings and between 1 and 10 chlorine atoms substituted on each of the benzene molecule [3]. PCBs have numerous industrial and other applications as dielectric fluids and insecticides [4]. PCBs have been reported to cause many adverse health effects, such as immune deficiency, nervous system alteration, endocrine disruption, and gastrointestinal system bleeding and liver damage [5]. Many sludge were reported to be contaminated with polychlorinated biphenyls at elevated levels, 6 - $2500 \mu \mathrm{g} / \mathrm{kg}$ [6]-[15]. Limited PCB congeners in soils of industrial cities of the country were reported by Kumar et al. [16] [17]. Therefore, in this work, the contamination, distribution and sources of PCBs congeners ( $>50)$ in the agricultural, industrial and municipal wastes of the most industrialized area of central India: Raipur, Chhattisgarh, India are described.

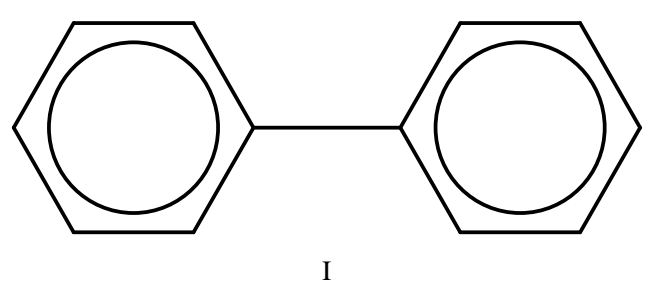

\section{Methods and Materials}

\subsection{Selection of Studies Areas}

Iron and steel is one of the largest sectors of industries in the central India. Iron ore is smelted in blast furnace with coke and lime to produce pig iron and generates a huge amount of waste. The one of the Asia biggest steel plant (capacity of 4.8 MT iron/Yr) is running nearby Raipur city at Bhilai with subsequent dumping of the industrial effluents. Several coal based thermal power plants are operated for generation of electricity by dumping waste materials in the nearby area. The Rice is major agricultural crops in central region of the country which generate a huge amount of the biomass waste. Large quantity ( $\approx 300$ million lit/day) of untreated sewage waste is discharged into the environment. Hence, these wastes were selected for monitoring of the PCBs congeners.

\subsection{Sample Collection}

Six samples i.e. sludge, sewage and burnt agricultural wastes were collected in month of May, 2009 using a stainless-steel scoop. The sampling locations (i.e. Bhilai Steel Plant dumping pond, Monet thermal power plant waste, Urla municipal waste and IGAU rice field agricultural waste) are shown in Figure 1. They were kept in a $250-\mathrm{mL}$ glass bottle and dried at $30^{\circ} \mathrm{C}$ in an oven for overnight. The samples were crushed into fine particles by mortar and sieved out the particles of mesh size $<0.1 \mathrm{~mm}$. The samples were stored in aluminum foil by freezing at $-4^{\circ} \mathrm{C}$.

\subsection{Analysis}

The sediment ( $5.0 \mathrm{~g}$ ) was extracted with 25 -mL distilled water by subsequent decanting out the extract for the pH measurement. The CHNSO-IRMS Analyzer (SV Instruments Analytica Pvt. Ltd.) was used for analysis of the total carbon (TC) and black or elemental carbon (BC or EC). The soil sample (15 mg) was oxidized with $\mathrm{O}_{2}$ at $1020^{\circ} \mathrm{C}$ with constant helium flow by measuring the resulting $\mathrm{CO}_{2}$ gas with a thermal conductivity detector The $\mathrm{H}_{3} \mathrm{PO}_{4}(10$ drops) treated soil sample was oxidized in a similar way for determination of $\mathrm{BC}$ and organic carbon (OC) content. The OC content was analyzed by titration method using $\mathrm{K}_{2} \mathrm{Cr}_{2} \mathrm{O}_{7}$ as oxidant [18]. The carbonate carbon (CC) content in the soil was evaluated by subtracting the $\mathrm{BC}+\mathrm{OC}$ to the TC content by using the following equation.

$$
\mathrm{CC}=\mathrm{TC}-(\mathrm{BC}+\mathrm{OC})
$$

The dried waste sample was extracted with mixed solvent: methylene chloride + methanol (1:1, v/v) by using a Dionex accelerated solvent extraction (ASE) system. The extract was evaporated, and re-extracted with solvent, methylene chloride by subsequent addition of the surrogate standards. The extract was purified by silica/alumina column chromatography to isolate the PCB fractions [19]. The quantitative analyses of PCBs were performed by HP 5890-GC (gas chromatography) and HP 5970-MS (mass spectrometer) in the SIM mode [20]. 


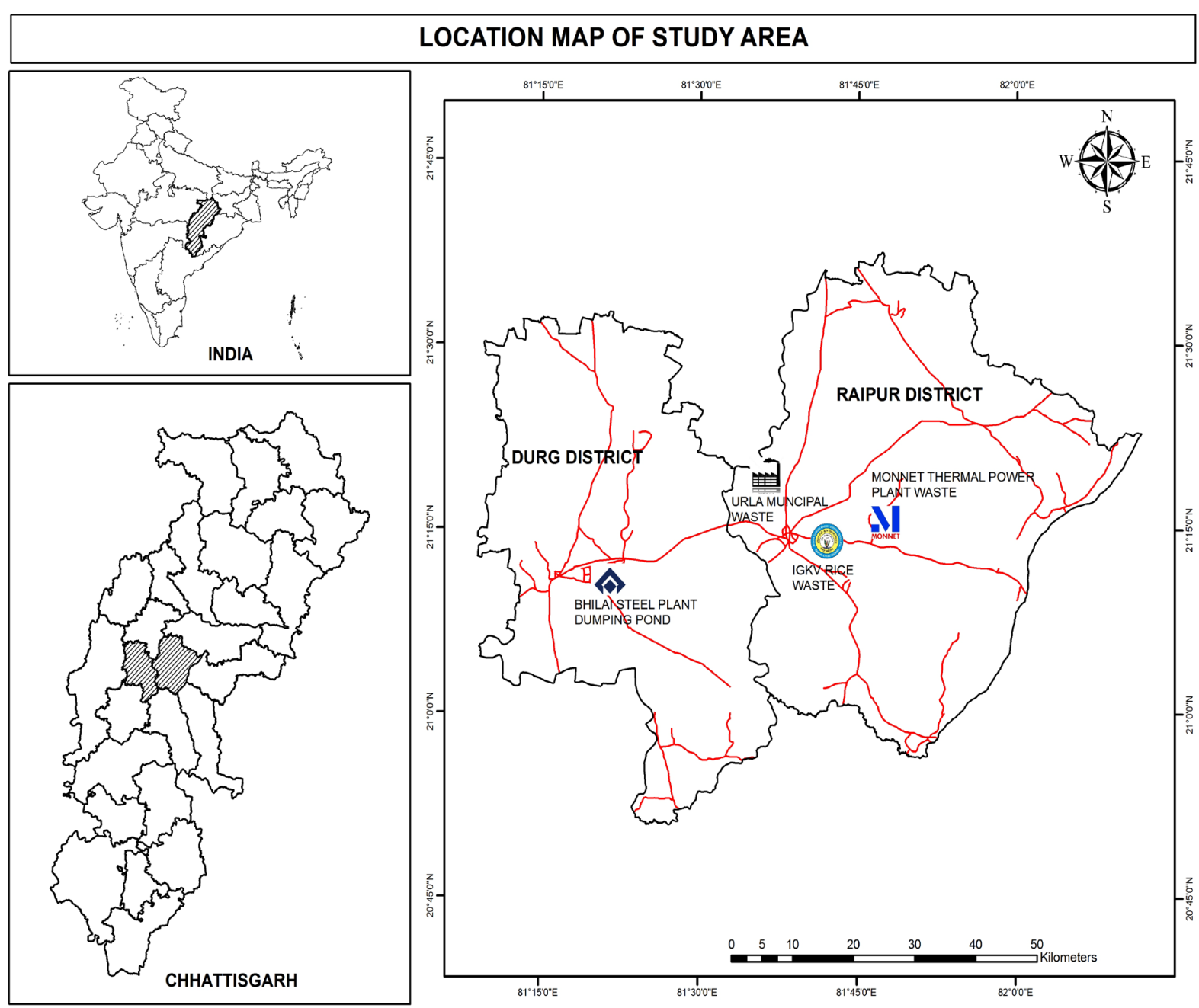

Figure 1. Representation of sampling locations.

\section{Results and Discussion}

PCBs are mixtures of 209 individual chlorinated compounds with chemical formula of $\mathrm{C}_{12} \mathrm{H}_{10-n} \mathrm{Cl}_{n}$, where $n$ ranges from 1 to 10. The chemical description of PCBs are summarized in Table 1.

\section{1. pH of Extract}

The $\mathrm{pH}$ value of the extract $(\mathrm{n}=4)$ was ranged from 7.8 - 8.4 with mean value of $8.1 \pm 0.2$. All the extracts were found to be slightly alkaline in nature. The lowest $\mathrm{pH}$ value of the sludge sample was recorded. The $\mathrm{pH}$ value of the sludge extract was found to be increase slightly as the depth profile of the sludge was increased from 0 - 30 cm, Table 2.

\subsection{Carbon Concentration}

The carbon content of the waste materials are presented in Table 2. The concentration of BC, OC and CC ( $\mathrm{n}=4$ ) was ranged from $7.5 \%-9.0 \%, 0.03 \%-0.05 \%$ and $0.11 \%-0.19 \%$ with mean value of $8.3 \pm 0.8,0.04 \pm 0.01$ and $0.15 \% \pm 0.04 \%$, respectively. The BC had fair correlation with the OC and CC content ( $\mathrm{r}=0.93-0.97)$, indicating their origin from the same sources. The BC concentration was found to decrease with increasing depth profile from 0 to $30 \mathrm{~cm}$ unlikely to the OC and CC. The BC content in the waste materials of the Raipur area was found to be higher than other region of the World, probably due to higher coal burning in this region [21]-[23]. 
Table 1. Description of PCBs.

\begin{tabular}{ccccc}
\hline Compound & Congener number & Abbreviation & Molecular weight & Formulae \\
\hline Monochlorobiphenyls & 3 & MCBs & 189 & $\mathrm{C}_{12} \mathrm{H}_{9} \mathrm{Cl}$ \\
Dichlorobiphenyls & 12 & DCBs & 233 & $\mathrm{C}_{12} \mathrm{H}_{8} \mathrm{Cl}_{2}$ \\
Trichlorobiphenyls & 24 & TCBs & 258 & $\mathrm{C}_{12} \mathrm{H}_{7} \mathrm{Cl}_{3}$ \\
Tetrachlorobiphenyls & 42 & TeCBs & 292 & $\mathrm{C}_{12} \mathrm{H}_{6} \mathrm{Cl}_{4}$ \\
Pentachlorobiphenyls & 46 & PeCBs & 326 & $\mathrm{C}_{12} \mathrm{H}_{5} \mathrm{Cl}_{5}$ \\
Hexachlorobiphenyls & 42 & HCBs & 361 & $\mathrm{C}_{12} \mathrm{H}_{4} \mathrm{Cl}_{6}$ \\
Heptachlorobiphenyls & 24 & HeCBs & 395 & $\mathrm{C}_{12} \mathrm{H}_{3} \mathrm{Cl}_{7}$ \\
Octachlorobiphenyls & 12 & OCBs & 430 & $\mathrm{C}_{12} \mathrm{H}_{2} \mathrm{Cl}_{8}$ \\
Nonachlorobiphenyls & 3 & NCBs & 189 & $\mathrm{C}_{12} \mathrm{HCl}_{9}$ \\
Decachlorobiphenyls & 1 & DeCBs & 233 & $\mathrm{C}_{12} \mathrm{Cl}_{10}$ \\
\hline
\end{tabular}

Table 2. Carbon content in waste materials, \%.

\begin{tabular}{ccccc}
\hline Waste material & $\mathrm{pH}$ & $\mathrm{BC}$ & OC & CC \\
\hline Sl1 & 8.4 & 7.5 & 0.03 & 0.12 \\
Sl2 & 8.6 & 7.3 & 0.06 & 0.15 \\
Sl3 & 9.1 & 7.1 & 0.09 & 0.18 \\
TPPW & 8.1 & 8.9 & 0.04 & 0.17 \\
AW & 7.8 & 9.0 & 0.05 & 0.19 \\
MW & 8.0 & 7.6 & 0.03 & 0.11 \\
\hline
\end{tabular}

Sl1, Sl2 and Sl3 denote the Bhilai steel plant sludge collected at depth of $0-10,10-20$ and $20-30 \mathrm{~cm}$; TPPW = Monate thermal power plant waste; $\mathrm{AW}=$ Agricultural waste; $\mathrm{MW}=$ Municipal (sewage) waste.

\subsection{Total PCBs Concentration}

The PCBs contents in the waste material is summarized in Table 3. The sum of total concentration of PCBs in 4 different types of waste materials (Sl1, TPPW, MW and AW) was ranged from $497-800 \mu \mathrm{g} / \mathrm{kg}$ with mean value of $634 \pm 146 \mu \mathrm{g} / \mathrm{kg}$. The highest concentration of the PCBs was observed in the AW sample due to the excessive input of the congener 3 . The large fraction of the PCBs, $68 \%-84 \%$ in all samples was contributed by the monochlorobiphenyls (MCBPs), Figure 2.

\subsection{Spatial Distribution of Congeners}

The observed congener frequency of the PCBs in the Sl, TPPW, MW and AW was found to be 85, 77, 81 and 56, respectively, Figure 3. The highest concentration of MCBPs was observed in the AW, may be due to chlorination of the biphenyls, Figure 4(a). The highest concentration of DCBPs and TCBPs to HCBPs was marked in the TPPW and MW, Respectively, Figure 4(b) and Figure 4(c).

\subsection{Vertical Distribution of PCBs}

The vertical distribution of $\Sigma$ PCBs concentration and congeners are presented in Table 3. Both concentration and congener numbers of PCBs were found to decrease as the depth profile of the sludge was increased from 0 $30 \mathrm{~cm}$, may be due to their adsorption by the sludge matrix and biodegradation, Figure 5 and Figure 6 . At least $42 \%$ estimated congeners in the sludge was found to exist in the sludge, Figure 5. The congener frequency was increased up to TeCBPs, and thereafter, decreased slowly up to HeCBs, Figure 5.

In general, the concentration of MCBPs, DCBPs, TCBPs, PCBs, HCBPs and HeCBPs was found to decease as the depth profile of the sludge was increased from $0-30 \mathrm{~cm}$, Figure 6. However, the reverse trend was seen 
Table 3. Distribution of PCBs congeners in waste materials, $\mu \mathrm{g} / \mathrm{kg}$.

\begin{tabular}{|c|c|c|c|c|c|c|c|}
\hline Type of PCBs & Congener & Sl1 & $\mathrm{Sl} 2$ & Sl3 & TPPW & MW & AW \\
\hline \multirow[t]{2}{*}{ MCBPs } & 1 & 111.9 & 86.5 & 28.6 & 127.9 & 148.4 & 254.7 \\
\hline & 3 & 374.3 & 188.6 & 305.3 & 226.5 & 69.7 & 414.4 \\
\hline \multirow[t]{4}{*}{ DCBPs } & $4+10$ & 7.6 & 5.8 & 3.9 & 7.6 & 0.0 & 0.0 \\
\hline & $7+9$ & 1.3 & 1.0 & 1.5 & 1.2 & 0.3 & 0.7 \\
\hline & 6 & 3.8 & 2.1 & 0.2 & 3.6 & 2.3 & 3.4 \\
\hline & $8+5$ & 15.6 & 12.9 & 0.4 & 16.0 & 18.4 & 15.1 \\
\hline \multirow[t]{11}{*}{ TCBPs } & 19 & 2.8 & 2.1 & 1.3 & 1.2 & 2.5 & 2.0 \\
\hline & 18 & 1.8 & 2.4 & 1.6 & 2.1 & 5.7 & 1.8 \\
\hline & 17 & 5.8 & 5.6 & 4.3 & 5.1 & 7.0 & 0.0 \\
\hline & 24 & 0.0 & 0.0 & 0.0 & 0.0 & 1.5 & 0.0 \\
\hline & $16+32$ & 3.3 & 2.2 & 1.9 & 2.5 & 2.2 & 7.2 \\
\hline & 29 & 1.4 & 1.1 & 1.9 & 1.2 & 0.1 & 2.0 \\
\hline & 26 & 3.9 & 1.9 & 2.1 & 3.1 & 1.3 & 2.3 \\
\hline & 25 & 1.1 & 1.9 & 1.5 & 1.7 & 1.0 & 3.0 \\
\hline & $28+31$ & 3.8 & 2.8 & 3.7 & 3.8 & 8.2 & 4.8 \\
\hline & 22 & 4.2 & 3.0 & 2.3 & 3.7 & 1.9 & 3.1 \\
\hline & $21+33+53$ & 3.3 & 2.4 & 2.8 & 3.0 & 3.3 & 2.3 \\
\hline \multirow[t]{14}{*}{ TeCBPs } & 51 & 2.9 & 2.2 & 2.2 & 2.6 & 0.0 & 0.0 \\
\hline & 45 & 2.3 & 1.7 & 1.0 & 2.3 & 1.0 & 1.2 \\
\hline & 46 & 1.6 & 2.3 & 0.0 & 1.4 & 2.1 & 2.4 \\
\hline & 62 & 2.9 & 2.0 & 0.6 & 2.5 & 4.1 & 1.6 \\
\hline & 49 & 2.4 & 1.8 & 0.0 & 2.3 & 8.1 & 5.1 \\
\hline & $47+48$ & 2.0 & 1.6 & 0.5 & 1.4 & 2.3 & 0.0 \\
\hline & 44 & 0.8 & 0.6 & 0.5 & 2.4 & 2.0 & 1.3 \\
\hline & $37+42$ & 7.1 & 5.2 & 2.9 & 4.7 & 4.0 & 2.3 \\
\hline & $41+64+71$ & 4.6 & 11.6 & 5.9 & 7.2 & 3.2 & 23.1 \\
\hline & 63 & 0.0 & 0.0 & 1.1 & 1.5 & 0.0 & 0.0 \\
\hline & 74 & 2.3 & 2.6 & 2.6 & 2.7 & 3.2 & 2.6 \\
\hline & 70.76 & 3.2 & 2.5 & 2.2 & 2.3 & 7.3 & 5.2 \\
\hline & $66+95$ & 2.7 & 2.5 & 1.7 & 2.0 & 4.0 & 3.6 \\
\hline & $56+60$ & 5.2 & 4.2 & 24.7 & 0.0 & 20.2 & 10.2 \\
\hline \multirow[t]{8}{*}{ PCBPs } & 91 & 0.0 & 0.0 & 0.0 & 0.0 & 0.0 & 0.0 \\
\hline & 100 & 2.0 & 1.6 & 1.2 & 1.7 & 1.7 & 3.9 \\
\hline & 105 & 6.6 & 6.2 & 2.5 & 5.9 & 5.9 & 0.0 \\
\hline & 89 & 4.2 & 0.0 & 0.0 & 1.7 & 14.4 & 0.0 \\
\hline & 101 & 3.0 & 1.5 & 1.3 & 1.3 & 6.9 & 2.3 \\
\hline & 99 & 2.4 & 1.2 & 0.8 & 0.7 & 2.1 & 0.7 \\
\hline & 83 & 1.0 & 1.9 & 0.3 & 0.2 & 1.9 & 3.0 \\
\hline & 97 & 1.0 & 0.6 & 0.1 & 0.1 & 5.9 & 0.3 \\
\hline
\end{tabular}




\begin{tabular}{|c|c|c|c|c|c|c|c|}
\hline \multicolumn{8}{|l|}{ Continued } \\
\hline & $81+87$ & 1.2 & 0.8 & 0.3 & 0.0 & 0.0 & 0.0 \\
\hline & 85 & 0.9 & 0.6 & 0.3 & 0.3 & 1.1 & 0.0 \\
\hline & $77+110$ & 10.3 & 13.3 & 4.2 & 8.6 & 6.7 & 4.6 \\
\hline & $82+151$ & 4.7 & 5.6 & 0.0 & 0.0 & 0.0 & 0.0 \\
\hline & $123+149$ & 12.0 & 11.8 & 2.9 & 5.8 & 8.9 & 0.0 \\
\hline & 118 & 4.9 & 6.4 & 1.7 & 3.5 & 3.0 & 0.0 \\
\hline \multirow[t]{12}{*}{ HCBPs } & 134 & 14.7 & 15.1 & 0.0 & 0.0 & 6.3 & 0.0 \\
\hline & 146 & 7.5 & 5.7 & 0.0 & 0.0 & 0.0 & 0.0 \\
\hline & 136 & 6.3 & 5.9 & 1.2 & 2.4 & 4.8 & 0.0 \\
\hline & 132 & 3.8 & 5.7 & 1.5 & 3.0 & 5.3 & 0.0 \\
\hline & $135+144$ & 3.3 & 2.4 & 0.9 & 3.8 & 4.2 & 0.0 \\
\hline & 153 & 14.3 & 11.2 & 3.0 & 8.3 & 17.1 & 0.0 \\
\hline & 157 & 2.2 & 0.0 & 2.2 & 0.0 & 1.7 & 0.0 \\
\hline & 141 & 3.3 & 2.4 & 0.6 & 2.0 & 1.8 & 0.0 \\
\hline & $137+130+176$ & 2.2 & 2.4 & 0.0 & 2.2 & 3.1 & 0.0 \\
\hline & $138+158$ & 5.7 & 3.9 & 1.6 & 4.5 & 31.2 & 5.5 \\
\hline & 163 & 6.6 & 5.9 & 3.5 & 7.5 & 0.0 & 0.0 \\
\hline & $129+178$ & 5.2 & 14.1 & 9.1 & 10.1 & 4.0 & 0.0 \\
\hline \multirow[t]{4}{*}{ HeCBPs } & 183 & 2.8 & 0.0 & 0.0 & 0.0 & 5.4 & 0.0 \\
\hline & 185 & 0.5 & 0.0 & 0.0 & 0.4 & 2.6 & 0.0 \\
\hline & 177 & 1.5 & 0.0 & 0.0 & 0.0 & 3.2 & 0.0 \\
\hline & 201 & 0.0 & 0.0 & 0.0 & 0.0 & 5.0 & 0.0 \\
\hline \multirow[t]{2}{*}{ OCBPs } & $208+195$ & 0.0 & 0.0 & 0.0 & 0.0 & 6.9 & 0.0 \\
\hline & 194 & 0.0 & 1.4 & 0.0 & 0.0 & 0.8 & 4.1 \\
\hline
\end{tabular}

MCBPs, DCBPs, TCBPs, TeCBPs, PCBPs, HCBPs, HeCBPs and OCBPs denotes the mono, di, tri, tetra, penta, hexa, hepta and octachloro-derivative of BPs.

with TeCBPs. The following four different scenarios for the PCBs depth profile distribution was observed. The concentration of large number of congeners was found to decrease when the depth profile was increased, may be due to strong adsorption by the sludge matrix (Table 3). The concentration of some congeners (i.e. 63, 56, 60 and 74) was found to increase as the depth profile was increased, may be due to less adsorption by the sludge matrix. However, the concentration of few congeners (i.e. 7, 9, 18, 21, 25, 29, 33, 41, 51, 53, 64, 71, 129 and 178) was unaffected with respect to increasing depth profile, may be due to being nonpolar in nature. Some heavy congeners i.e. 183, 185, 177 and 201 was observed to be appeared in the surface sludge.

\subsection{Toxicities}

The coplanar PCBs (i.e. 77, 126 and 169) having dioxin-like properties were reported to be the most toxic congeners [24]. Among them, the congener 77 existed in all samples, and its concentration was not found to be affected with respect to increasing depth profile from 0 to $30 \mathrm{~cm}$. The PCBPs in all waste materials of the studied area was found to be several folds higher than the recommended value of $60 \mu \mathrm{g} / \mathrm{kg}$ soil [25].

\subsection{Sources}

The most common trade name of PCBs is Aroclor, being mixture of higher chlorinated biphenyls. The content of PCBs (i.e. MCBPs, DCBPs, TCBPs and TeCBPs) among themselves had good correlation $(\mathrm{r}=0.97)$ in the 
SL

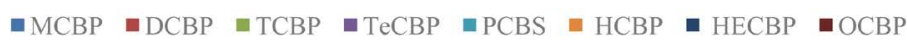

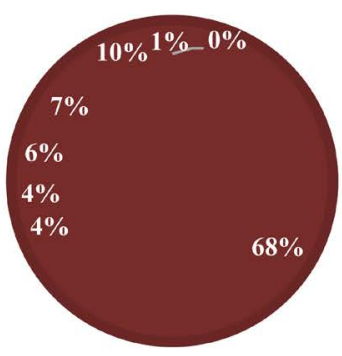

MW

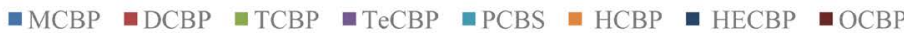

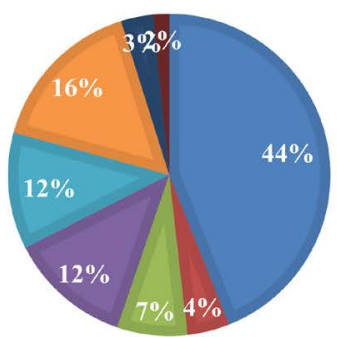

MW

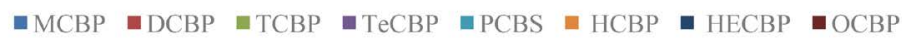

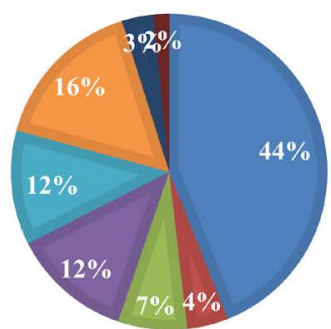

Figure 2. Relative concentration of MCBPs, DCBPs, TCBPs, TeCBPs, PCBPs, HCBPs, HeCBPs and OCBPs in the waste materials.

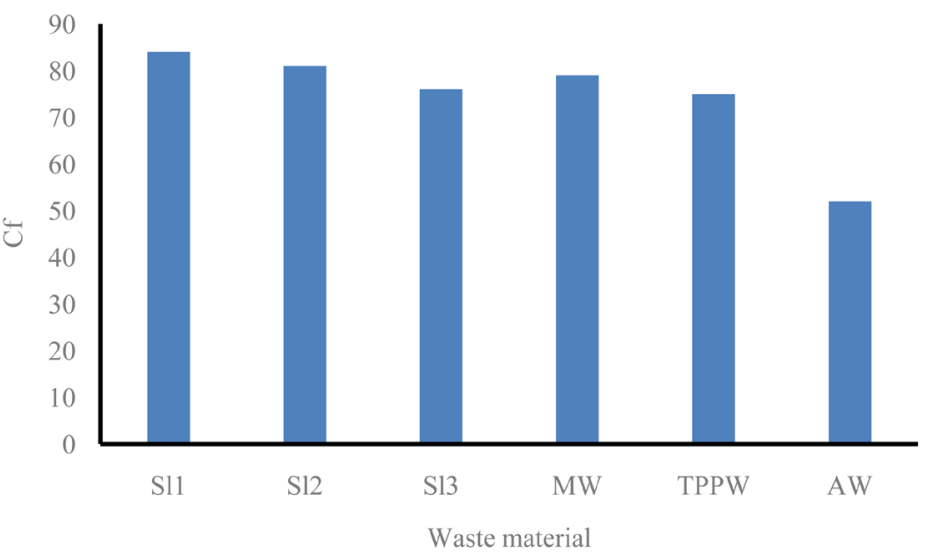

Figure 3. Representation of congener frequency in the waste material. 


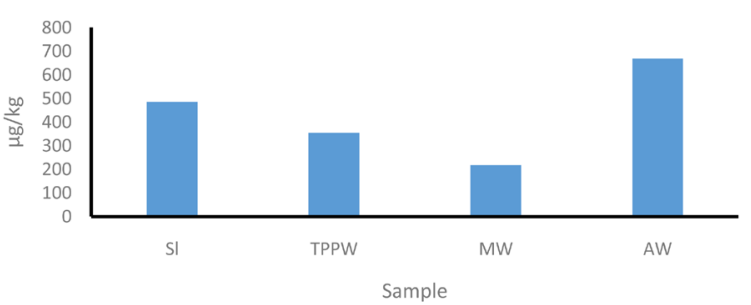

(a)

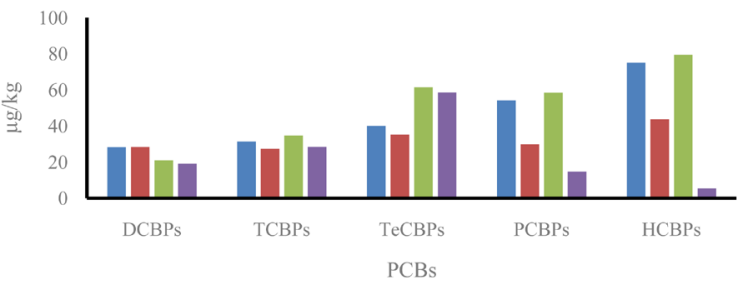

- $\mathrm{Sl}=\mathrm{TPPW}=\mathrm{MW} \backsim \mathrm{AW}$

(b)

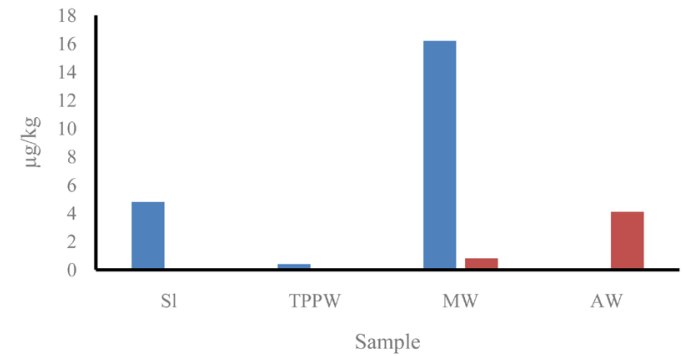

- $\mathrm{HeCBPs}$ - OCBPs

(c)

Figure 4. Representation of mono, di, tri, tetra, penta, hexa, hepta and octachloro derivatives of BPs.

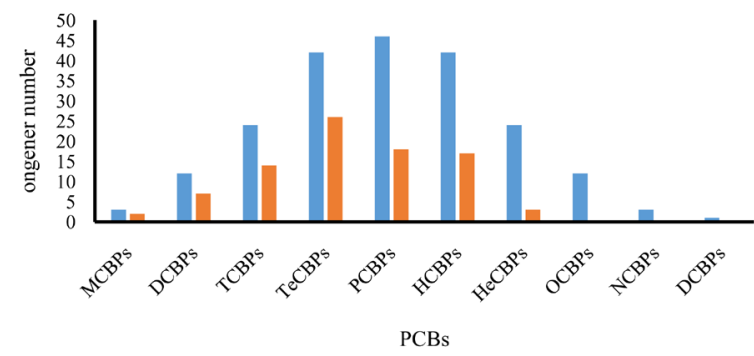

$=\mathrm{EN}=\mathrm{ON}$

(a)

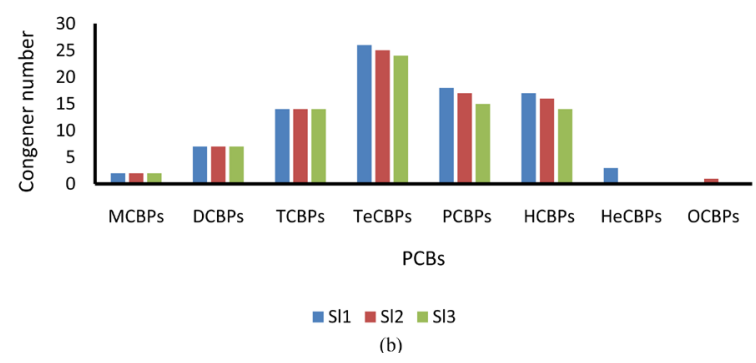

Figure 5. Congener distribution in the environmental samples, EN = Estimated congeners, ON = Observed congeners, $\mathrm{Sl} 1=0-10 \mathrm{~cm}, \mathrm{Sl} 2=10-20 \mathrm{~cm}, \mathrm{Sl} 3=20-30 \mathrm{~cm}$. 


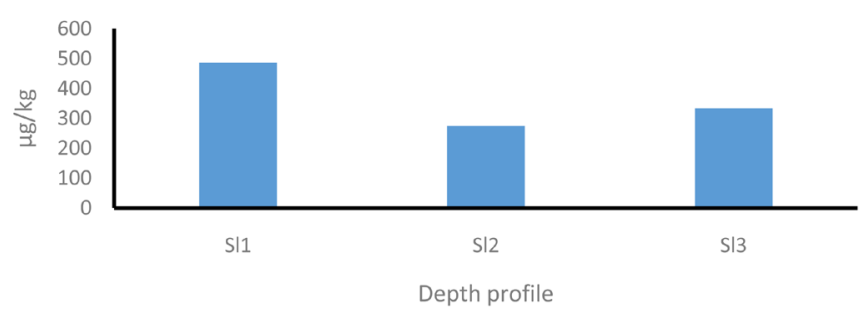

(a)

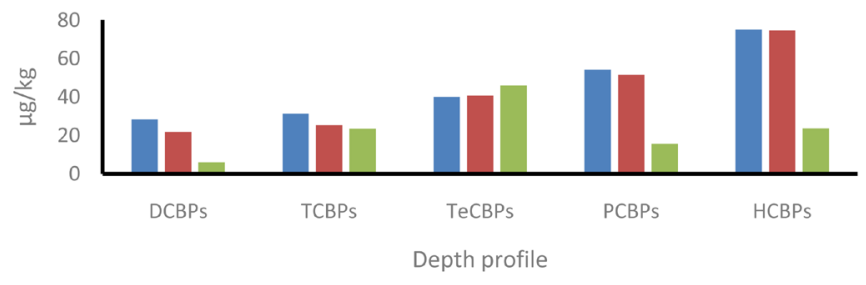

$\square \mathrm{SI}=\mathrm{SI}=\mathrm{SI}$

(b)

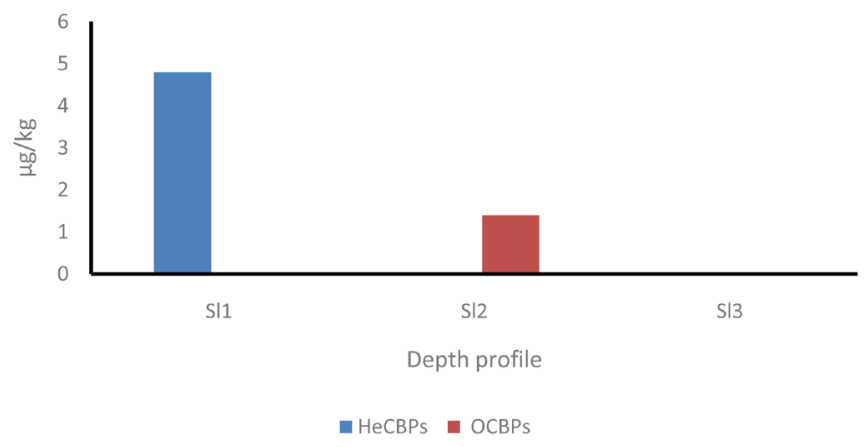

(c)

Figure 6. Depth profile studies of PCBs in the sludge, Sl1 = 0 - 10 $\mathrm{cm}, \mathrm{Sl} 2=10-20 \mathrm{~cm}, \mathrm{Sl} 3=20-30 \mathrm{~cm}$.

sludge. However, the higher PCBs (i.e. PCBPs, HCBPs, HeCBPs and OCBPs) had fair correlation $(r=0.60)$, indicating origin from multiple sources. It means the lower PCBs could be generated by the chlorination processes of the BPs. The higher PCBs are released in the environments by leakage from the application sites.

$$
\begin{gathered}
\mathrm{C}_{12} \mathrm{H}_{10}+\mathrm{Cl}_{2} \rightarrow \mathrm{C}_{12} \mathrm{H}_{9} \mathrm{Cl}+\mathrm{HCl} \\
\mathrm{C}_{12} \mathrm{H}_{9} \mathrm{Cl}+\mathrm{Cl}_{2} \rightarrow \mathrm{C}_{12} \mathrm{H}_{8} \mathrm{Cl}_{2}+\mathrm{HCl} \\
\mathrm{C}_{12} \mathrm{H}_{8} \mathrm{Cl}_{2}+\mathrm{Cl}_{2} \rightarrow \mathrm{C}_{12} \mathrm{H}_{7} \mathrm{Cl}_{3}+\mathrm{HCl} \\
\mathrm{C}_{12} \mathrm{H}_{7} \mathrm{Cl}_{3}+\mathrm{Cl}_{2} \rightarrow \mathrm{C}_{12} \mathrm{H}_{6} \mathrm{Cl}_{4}+\mathrm{HCl}
\end{gathered}
$$

\section{Conclusion}

Significantly higher concentrations of PCBs in the industrial and municipal waste materials of Raipur region of the country were observed. The major fraction of the PCBs was contributed by the congeners, 1 and 3 . The PCBs concentration and congeners were decreased with respect to depth profile of the sludge. The origin of lower PCBs was expected by the chlorination of the biphenyl. However, origin of higher PCBs was assumed from leakage or evaporation from the application sites. The NCBPs and DCBPs were not detected in waste materials.

\section{Acknowledgements}

We are thankful to the National Taiwan Ocean University, Keelung, Taiwan for providing fellowship to one of 
author: Saroj Sharma for doing this work.

\section{References}

[1] Weber, R., Gaus, C., Tysklind, M., Johnston, P., Forter, M., Hollert, H., Heinisch, E., Holoubek, I., Lloyd-Smith, M., Masunaga, S., Moccarelli, P., Santillo, D., Seike, N., Symons, R., Torres, J.P., Verta, M., Varbelow, G., Vijgen, J., Watson, A., Costner, P., Woelz, J., Wycisk, P. and Zennegg, M. (2008) Dioxin- and POP-Contaminated Sites-Contemporary and Future Relevance and Challenges: Overview on Background, Aims and Scope of the Series. Environmental Science and Pollution Research International, 15, 363-393. http://dx.doi.org/10.1007/s11356-008-0024-1

[2] Nguyen, H.M., Tu, B.M., Watanabe, M., Kunisue, T., Monirith, I., Tanabe, S., Sakai, S., Sasikumar, K., Bui, C.T., Tana, T.S., Annamalai, S., Viet, P.H. and Prudente, M.S. (2003) Open Dumping Site in Asian Developing Countries: A Potential Source of Polychlorinated Dibenzo-P-Dioxins and Polychlorinated Dibenzofurans. Environmental Science and Technology, 37, 1493-1502. http://dx.doi.org/10.1021/es026078s

[3] ATSDR (2001) Polychlorinated Biphenyls, Agency for Toxic Substances and Disease Registry. http://www.atsdr.cdc.gov/tfacts17.html

[4] UNEP (2004) Inventory of World-Wide PCB Destruction Capacity. United Nations Environment Programme, UNEP Chemicals, Geneva. http://www.chem.unep.ch/POPs/pcb_activities/pcb_dest/PCB_Dest_Cap_SHORT.pdf

[5] IPCS (2003) Polychlorinated Biphenyls: Human Health Aspects. World Health Organization, International Programme on Chemical Safety Concise International Chemical Assessment Document 55, Geneva.

http://www.inchem.org/documents/cicads/cicads/cicad55.htm

[6] McGrath, D., Postma, L., McCormack, R.J. and Dowdall C. (2000) Analysis of Irish Sewage Sludges: Suitability of Sludge for Use in Agriculture. Irish Journal of Agricultural and Food Research, 39, 73-78. http://www.jstor.org/stable/25562373

[7] Bright, D.A. and Healey N. (2003) Contaminant Risks from Biosolids Land Application: Contemporary Organic Contaminant Levels in Digested Sewage Sludge from Five Treatment Plants in Greater Vancouver, British Columbia. Environmental Pollution, 126, 39-49. http://dx.doi.org/10.1016/S0269-7491(03)00148-9

[8] Stevens, J.L., Northcott, G.L., Stern, G.A., Tomy, G.T. and Jones, K.C. (2003) PAHs, PCBs, PCNs, Organochlorine Pesticides, Synthetic Musks, and Polychlorinated $n$-Alkanes in U.K. Sewage Sludge: Survey Results and Implications. Environmental Science and Technology, 37, 462-467. http://dx.doi.org/10.1021/es020161y

[9] Blanchard, M., Teil, M.J., Ollivon, D., Legenti, L. and Chevreueil, M. (2004) Polycyclic Aromatic Hydrocarbons and Polychlorobiphenyls in Wastewaters and Sewage Sludgs from the Paris Area (France). Environmental Research, 95, 184-197. http://dx.doi.org/10.1016/j.envres.2003.07.003

[10] Katsoyiannis, A. and Samara, C. (2004) Persistent Organic Pollutants (POPs) in the Sewage Treatment Plant of Thessaloniki, Northern Greece: Occurrence and Removal. Water Research, 38, 2685-2698. http://dx.doi.org/10.1016/j.watres.2004.03.027

[11] Abad, E., Martínez, K., Planas, C., Palacios, O., Caixach, J. and Rivera, J. (2005) Priority Organic Pollutant Assessment of Sludges for Agricultural Purposes. Chemosphere, 61, 1358-1369. http://dx.doi.org/10.1016/j.chemosphere.2005.03.018

[12] Harrison, E.Z., Oakes, S.R., Hysell, M. and Hay, A. (2006) Organic Chemicals in Sewage Sludges. Science of the Total Environment, 367, 481-497. http://dx.doi.org/10.1016/j.scitotenv.2006.04.002

[13] Cai, Q.Y., Mo, C.H., Wu, Q.T., Zeng, Q.Y. and Katsoyiannis, A. (2007) Occurrence of Organic Contaminants in Sewage Sludges from Eleven Wastewater Treatment Plants, China. Chemosphere, 68, 1751-1762. http://dx.doi.org/10.1016/j.chemosphere.2007.03.041

[14] Guo, L., Zhang, B., Xiao, K., Zhang, Q. and Zheng, M. (2009) Levels and Distributions of Polychlorinated Biphenyls in Sewage Sludge of Urban Wastewater Treatment Plants. Journal of Environmental Sciences, 21, 468-473. http://dx.doi.org/10.1016/S1001-0742(08)62293-7

[15] Clarke, B.O., Porter, N.A., Marriott, P.J. and Blackbeard, J.R. (2010) Investigating the Levels and Trends of Organochlorine Pesticides and Polychlorinated Biphenyl in Sewage Sludge. Environment International, 36, 323-329. http://dx.doi.org/10.1016/j.envint.2010.01.004

[16] Kumar, B., Verma, V.K., Kumar, S. and Sharma, C.S. (2013) Probabilistic Health Risk Assessment of Polycyclic Aromatic Hydrocarbons and Polychlorinated Biphenyls in Urban Soils from a Tropical City of India. Journal of Environmental Science and Health Part A, Toxic/Hazardous Substances \& Environmental Engineering, 48, 1253-1263. http://dx.doi.org/10.1080/10934529.2013.776894

[17] Kumar, B., Verma, V.K., Singh, S.A., Kumar, S., Sharma, C.S. and Akolkar, A.B. (2014) Polychlorinated Biphenyls in Residential Soils and their Health Risk and Hazard in an Industrial City in India. Journal of Public Health Research, 3, 252. http://dx.doi.org/10.4081/jphr.2014.252 
[18] Walkley, A. and Black, I.A. (1934) An Examination of the Degtjareff Method for Determining Soil Organic Matter and a Proposed Modification of the Chromic Acid Titration Method. Soil Science, 37, 29-38. http://dx.doi.org/10.1097/00010694-193401000-00003

[19] Wade, T.L., Atlas, E.L., Brooks, J.M., Kennicutt, M.C., Fox, R.G., Sericano, J., Garcia-Romero, B. and Defreitas, D. (1988) NOAA Gulf of Mexico Status and Trends Program: Trace Organic Contaminant Distribution in Sediments and Oysters. Estuaries, 11, 171-179. http://dx.doi.org/10.2307/1351969

[20] Sericano, J.L. (2002) Quantitative Determination of Polychlorinated Biphenyls by Gas Chromatography/Mass Spectrometry Using the Selected Ion Monitoring Mode, Texas A and M University. Geochemical and Environmental Research Group Standard Operating Procedures, SOP-0205, 24.

[21] Muri, G., Cermelj, B., Faganeli, J. and Brancelj, A. (2002) Black Carbon in Slovenian Alpine Lacustrine Sediments. Chemosphere, 46, 1225-1234. http://dx.doi.org/10.1016/S0045-6535(01)00295-8

[22] Grossman, A. and Ghosh, U. (2009) Measurement of Activated Carbon and Other Black Carbons in Sediments. Chemosphere, 75, 469-475. http://dx.doi.org/10.1016/j.chemosphere.2008.12.054

[23] Sun, X., Peng, P., Song, J., Zhang, G. and Hu, J. (2008) Sedimentary Record of Black Carbon in the Pearl River Estuary and Adjacent Northern South China Sea. Applied Geochemistry, 23, 3464-3472. http://dx.doi.org/10.1016/j.apgeochem.2008.08.006

[24] Sapozhnikova, Y., Zubcov, E., Zubcov, N. and Schlenk, D. (2005) Occurrence of Pesticides, Polychlorinated Biphenyls (PCBs), and Heavy Metals in Sediments from the Dniester River, Moldova. Archives of Environmental Contamination and Toxicology, 49, 439-448. http://dx.doi.org/10.1007/s00244-005-8011-8

[25] Bobovnikova, T., Dibtseva, A., Mitroshkov, A. and Pleskachevskaya, G. (1993) Ecological Assessment of a Region with PCB Emissions Using Samples of Soil, Vegetation and Breast Milk: A Case Study. Science of the Total Environment, 139-140, 357-364. http://dx.doi.org/10.1016/0048-9697(93)90033-3 